\section{THE AMAZON BASIN}

\section{DRAINAGE BASINS}
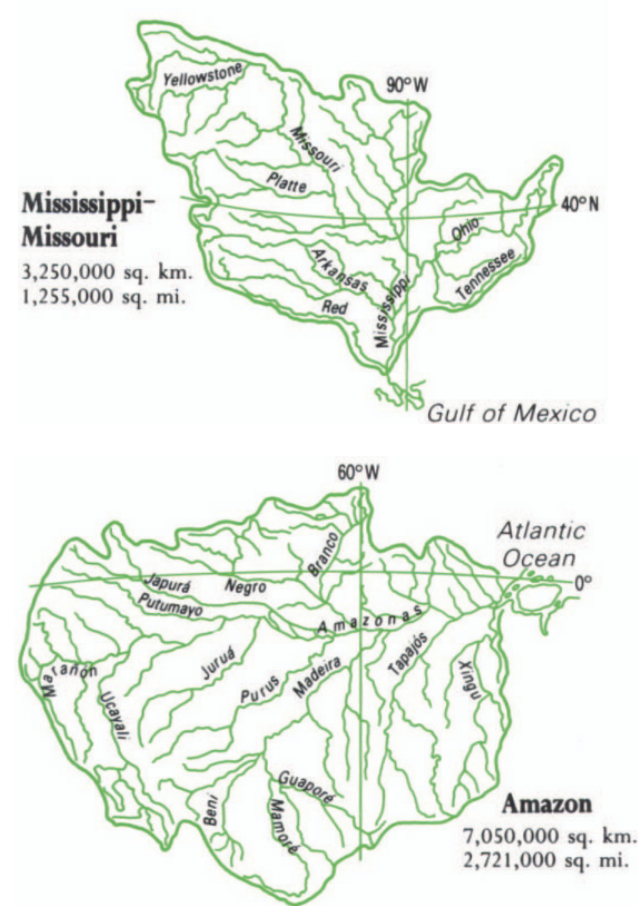

The Amazon Basin is by far the greatest river basin in the world. It drains an area of about 7 million square kilometers (2.73 million square miles), twice the area of the world's second largest basin, that of the river Zaiire (Congo) in Africa. Sloping down eastward from the foot of the Andes in the west, the enormous plains that make up most of the basin area border the Guiana Highlands in the north and the Brazilian Highlands in the south. The basin's lowlands are widest (about 1,400 kilometers [880 miles]) west of the confluence of the Amazon with the Rio Negro and narrowest (about 65 kilometers [ 40 miles]) near Santarém, where the Guiana and Brazilian highlands come closest. Most of the surface of the Amazon lowlands is an undulating plain, well above the floodplains of the rivers, whose main surface features are river terraces and bluffs which often stand 50 to 60 meters (160 to 200 feet) above the river. This is also by far the richest basin in water resources. The Amazon empties into the sea an average of 5,520 billion cubic meters of water per year (nearly four times that of the Zaïre, the river with the second largest discharge), or 11 percent of all the water drained from the world's continents into the seas. The discharge of the Amazon is highest in July, when the average flow is 216,000 cubic meters per second. It is lowest in November with an average of 73,000 cubic meters per second. The normal width of the channel varies from about 1.6 kilometers ( 1 mile) to 8 to 10 kilometers (5 to 6 miles). It is generally 6 to
12 meters (20 to 40 feet) deep, but it reaches a depth of nearly 100 meters (300 feet) in its narrow places. When in full flood, the Amazon usually extends over its entire floodplain (as do its tributaries) which at its narrowest parts is only about 30 kilometers (20 miles) wide, but over long stretches of its course is 80 to 100 kilometers (50 to 60 miles) wide. When in flood, the river carries large quantities of silt brought down from the highlands, which it deposits over its floodplain and opposite its mouth in the ocean, causing the discoloration of the seawater to a distance of about 300 kilometers (200 miles) offshore.

The channel of the Amazon has a very low gradient, descending only 170 meters (560 feet) from the foot of the Andes to the ocean over a course of more than 4,000 kilometers $(2,500$ miles). Over the last 1,400 kilometers ( 880 miles) of its course from Manaus, it descends only about 30 meters (100 feet). The river meanders over its floodplain, frequently shifting its channel, breaking into several arms, and forming lakes and swamps. The same applies to the courses of most of its tributaries in the lowlands. The Amazon is navigable to small ocean-going vessels (drawing up to 6 meters) up to Manaus and to small ships (drawing up to 4 meters) up to Iquitos in Peru. The Amazon tributaries that come down from the Guiana and Brazilian highlands are interrupted by falls and rapids. In most cases only their courses in the lowlands are navigable.

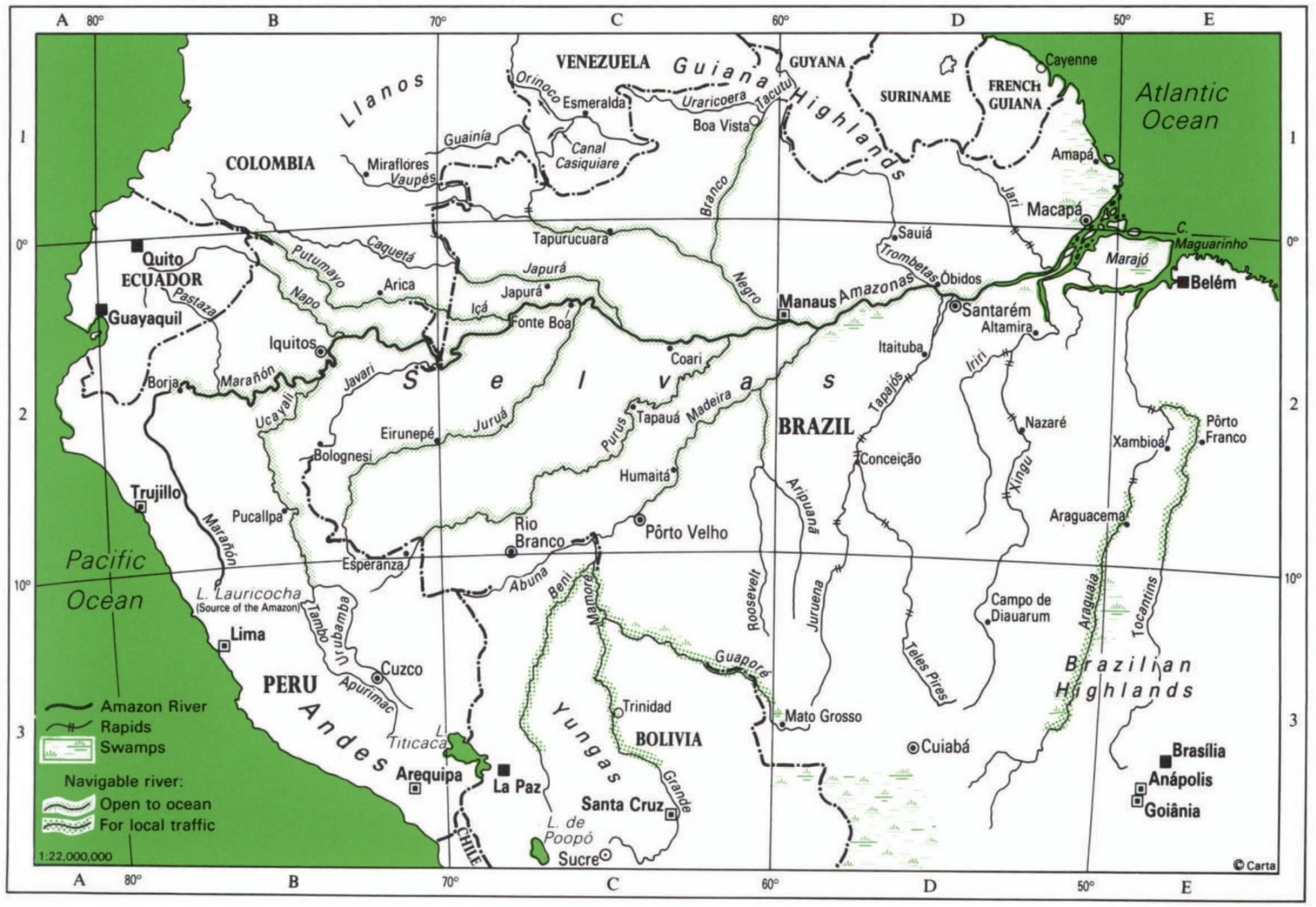

